\title{
BUILD LOCALLY, LINK GLOBALLY: THE SOCIAL FORUM PROCESS IN ITALY ${ }^{1}$
}

\author{
Donatella della Porta \\ Department of Political and Social Science \\ Europen University Institute \\ donatella.dellaporta@eui.eu
}

\author{
Lorenzo Mosca \\ Department of Political and Social Science \\ Europen University Institute \\ lorenzo.mosca@eui.eu
}

\begin{abstract}
Considered an innovation because of its capacity to develop transnational processes, the World Social Forum however also has strong local roots as well as effects on organizational models and collective identities at the domestic level. Focusing on the Italian case, this article shows how local social forums, as arenas for exchanges of ideas, played a cognitive role in the import, but also the translation of new ideas, as well as helping the emergence of dense network structures and tolerant identities. The first section of the article examines how local social forums contributed to innovation in the organizational formulas of the Global Justice Movement-considering both structure (organizations) and process (methodologies) aspects - through the development of different, more participatory conceptions of internal decision making. It then addresses the innovations in the definition of collective identities, stressing the linkages of local struggles and global framing as well as the development of a cross-issue discourse around an anti-neoliberal frame. The final section will discuss the contribution of local social forums to contemporary social movements, stressing the role of these new arenas for the cross-fertilization among different movement
\end{abstract}

\footnotetext{
${ }^{1}$ The empirical research for this article was conducted as part of the research project on "I social forum in Italia, Francia e Germania: tre diversi modelli di mobilitazione" (Social forums in Italy, France and Germany: three different models of mobilization) which is part of the more general project "Scienza politica e scienze cognitive. Nuovi paradigmi deliberativi per far fronte all'incertezza dei problemi poco strutturati” (Political science and cognitive sciences. New deliberative paradigms to face uncertainty in low structured problems), coordinated by Massimo Bonanni and financed by the Italian Ministry for the University and Research, and the research project DEMOS (Democracy in Europe and the Mobilization of the Society, http://demos.eui.eu), financed by the European Commission. Although the authors share responsibility for the whole article, Lorenzo Mosca wrote sections 1 and 2 and Donatella della Porta wrote sections 3 and 4. We wish to thank the editors of this special issue of the Journal of World-Systems Research and two anonymous referees for their useful comments on a previous version of this article.
} 
families and spreading a method of working together that becomes part of the repertoire of action of local social movement organizations. The empirical research consists mainly of in-depth interviews and focus groups with activists from social movement organizations which were involved in local social forums.

\section{LOCAL SOCIAL FORUMS AS BRIDGES: AN INTRODUCTION}

The World Social Forum (WSF) brought together a huge number of social movement organizations that were moving from concerns about specific issues to a broader opposition to neo-liberal globalization, as well as to the effects it has on social justice and democracy. It developed from within a history of transnational campaigns that addressed International Governmental Organizations from the ' 50 years is enough' mobilization against international financial organizations (in particular the IMF and the World Bank) to the debt campaign of Jubilee 2000, from the protests against the North American Free Trade Agreement (NAFTA) to the successful mobilization against the Multilateral Agreement on Investment (MAI), from the European Marches against Unemployment, targeting the European Union, to the UN of the Peoples. The WSF has in fact been welcomed (or feared) as a most visible sign of a transnationalization of politics, beyond the traditional boundaries of international relations. Recently, many activists and observers noticed a process of decentralization and re-localization of the WSF, symbolically stressed first by the polycentric structure of the 2006 annual event and then by the decentralized structure of the 2008 event. ${ }^{2}$ In addition, more and more attention has been paid to local (or national) struggles on employment issues and against the construction of big infrastructure projects (Pleyers 2007; della Porta and Piazza 2008). The local dimension of the social forum process is however not new. Many of the hundreds of organizations that participated in the WSF and its regional counterparts were local ones, or had strong local roots. ${ }^{3}$ The same can be said of the transnational campaigns that converged in the WSF which were "grounded by, and constituted of, a sense of place" (Drainville 2004: 17), as well as contributing to constructing a sense of place (57). The use of terms such as "rooted cosmopolitans" testifies to this complex linking of different identities (Tarrow 2005; della Porta and Tarrow 2005).

If the social forum process developed within local struggles, it also contributed to transforming them. As we argue in this article, a local dynamic developed in the social forum process along with the transnational one. In a process of cross-level diffusion, ideas of consensus and global justice spread across different (constructed) territory, with the local social forum acting as a sort of bridge between local and global concerns. They, and the organizations and groups that participated in them, adopted and adapted (or translated, to use De Sousa Santos' 2008 term) the ideas elaborated in the WSF at the local level. Transnational events provided activists with occasions to meet, build linkages of trust, exchange ideas, and network. The

\footnotetext{
${ }^{2}$ The eighth WSF did not take place in a particular venue because of the choice to organise a Global Day of Action worldwide in the same day (January $26^{\text {th }}$ ).

${ }^{3}$ It is worth noticing that what we define as "local social forum" can vary a lot from one country to another. While in Italy and France local social forums have been mainly organized at the local and municipal level, in other countries like Greece, Austria and Sweden they are organized at the national level (interview 1: 3).
} 


\section{JOURNAL OF WORLD-SYSTEMS RESEARCH}

emotional intensity and cognitive relevance of the WSF gave impulse to the spreading of an ethic (or "spirit") of reciprocal acceptance and respect as well as helping in linking local and global concerns. Local social forums promoted the mobilizations that followed by both facilitating relations of mutual trust between activists of different groups and by spreading horizontal and consensual decision-making as a way to construct new networks. The relationship of reciprocal knowledge and trust built during social forums activities spilled over to new networks. The experiences within the social forums and similar campaigns and activities pushed activists and organizations to bridge their specific concerns with more general and global ones.

We examine this process in one country, Italy, where the social forum process has been particularly relevant. The first and most visible social forum in Italy was the Genoa Social Forum (GSF), which brought together more than 800 groups (many of which were either local groups or local chapters of national and transnational ones) that organized the mobilization against the G8 summit in 2001 (Andretta et al. 2002; della Porta et al. 2006). Less visible but equally important have been, however, the large number of local social forums created just before and after the GSF. Many of them developed a few months before the protests against the G8 in Genoa (often under the label of anti-G8 coordination) in order to coordinate the mobilization. In most cases, they survived, and many more were formed in that year and in 2002. In the spring of 2003, shortly after the first European Social Forum (ESF) in Florence, 170 social forums were catalogued in Italy, in both urban and rural areas (della Porta 2005a and 2005b). Since 2003, many of the local social forums that disappeared were supplanted by either local organizing of the 'Stop the War' committee or gave birth to new networks on issues such as migrant rights or alternative life styles, thus contributing to the spreading of new organizational formulas.

As elsewhere, local social forums have operated as the backbone of the GJM.

The specificity of the Italian case can be linked to different structural and conjunctural characteristics. On the one hand, as a result of the corruption scandals of the early 1990s, a strong tradition of protest movements had developed into dense civic society networks outside the political institutional system. These networks nurtured simultaneously a criticism of the parties of the Left and opposition to the incoming right-wing government led by Silvio Berlusconi. On the other hand, in Italy the organization of significant "eventful" protests (such as the anti-G8 summit in 2001 and the first edition of the European Social Forum in 2002) contributed to creating a network of trust among activists as well as a collective identity, and broader societal support (della Porta et al. 2006). If the specificity of the Italian case makes our case study not fully generalizable, it provides however the possibility of observing the mechanisms of cross-level diffusion through a sort of magnifying lens.

In this article we bring together several different research projects carried out as part of a study of the GJM and local struggles. Our data is derived from in-depth interviews with representatives of social movement organizations and social forums which were conducted in Tuscany, Milan, and Venice, Novara and Abruzzo (a regional gathering of six territorial social forums $)^{4}$. To complete the picture, in 2007, we also interviewed the initiator of the European

\footnotetext{
${ }^{4}$ Interviews in Tuscany were conducted by Elena Del Giorgio; in Milan and in other Italian regions by Lorenzo Mosca.
} 
network of local social forums which, since 2004, has played a significant role in the ESF organizational process. ${ }^{5}$

Tuscany represents an interesting case, being the region where the first ESF was held in 2002, as well as having a traditionally rich milieu in terms of civil society's spread and reach. In Tuscany in 2003 in-depth interviews were carried out with members of six local social forums (Arezzo, Livorno, Lucca, Massa, Pisa and Prato). In this article, we also reference focus groups (FG) run in Florence in 2002 with six groups of activists of the local Florence social forum (della Porta 2005a). ${ }^{6}$ Milan was chosen as a paradigmatic case, having been considered for a long time the "capital" of social movements in Italy, but also having subsequently undergone a process of fragmentation of its social movement sector. In Milan, we interviewed 37 groups which had been involved in the local social forum in order to examine the transformative effects of such an experience on existing social movement organizations. Interviews were conducted between May and November 2004 using a semi-structured questionnaire focusing on the groups' history, organizational structure, decision-making methodology, modalities of action and framing, as related to globalization processes and to the social forum process in Italy. Interviews with representatives of other local social forums were carried out in 2006, within the framework of research on conceptions and practices of democracy in the Global Justice Movement (della Porta 2007). These local social forums were selected because they clearly represented examples of long-lasting experiences and thus appeared as crucial (even though not representative of the reality in the whole country) for looking at the social forum dynamic. We also reference other studies on local social forums in Italy.

In what follows we suggest that local social forums contributed to spreading new organizational formulas (the network, the method of consensus) and new frames (from single- to multi-issue, from local/national to transnational identities and opposition to neoliberalism). It is important to stress that our data refer to subjective memories. Our methodology entails a number of advantages and limitations. Semi-structured interviews encourage the emergence of interviewees' memories without placing them into too strict a framework. Moreover, the number of interviews is high enough to allow for the reconstruction and comparison of various organizational processes. The focus group, as a group interview, allows us to go beyond individual accounts and to look instead at the interactions between different actors (Touraine 1981; Melucci 1989; della Porta 2005c). However, our sources are stronger in investigating the subjective memories of the activists rather than in telling the "true" history of the mobilization. In fact, our aim is to reconstruct the narrative of the forums, as presented by the activists involved, considering these narratives as relevant for an understanding of the cultural and symbolic mechanisms involved in mobilization process (Polletta 2006).

\footnotetext{
${ }^{5}$ Interestingly, the promoter of the European network is an Italian trade unionist which was leaving in Manchester when the continental coordination was created. Afterwards, she moved to Greece where the following European Social Forum took place in May 2006.

${ }^{6}$ Focus groups were conducted with generational homogeneous groupings (15-19; 20-26; 27-35; 36-45; 46-60; 61-80) of between 7 and 9 people (overall 45 people were involved in them). Each group included activists of both genders, with different political backgrounds. The groups met with a researcher for about two hours in a university seminar room, discussing general questions about the movement and the social forum process. The meetings were taped and transcribed for qualitative analysis.
} 


\section{JOURNAL OF WORLD-SYSTEMS RESEARCH}

In the next section, we illustrate how local social forums contributed to innovation in the organizational formulas of the GJM-focusing on social movement organizations coming from different social movements (i.e. international solidarity, labor, ecologist, and feminist) considering both structural and process aspects - through the development of different, more participatory conceptions of internal decision making. We will then discuss the innovations they promoted in the definition of collective identities. The final section will illuminate the contribution of local social forums to contemporary social movements, stressing the role these new arenas play in the cross-fertilization of different movement families.

\section{TRANSFORMATIONS IN THE ORGANIZATIONAL STRUCTURE: NETWORKING AND CONSENSUS}

"The Turin Social Forum wants to be an open place in which also the individuals, as well as the organized actors, can meet and work together; a space in which internal differences are accepted and given positive value, and not considered as an instrument to be used in order to acquire larger visibility and impose working contents and methods; a space in which there should be no place for hegemonic attempts and instead the search for a sufficient degree of maturation and consensus as guiding principles for each initiative" (webdocument 5).

"We will experiment an organizational path that favors participation, research of consensus and achieving largely shared decisions" (webdocument 6).

Most Italian local forums such as the Turin Social Forum quoted above, reference the Charter of Principles of Porto Alegre and the "work agreement" of the Genoa social forum in their constitution. They present themselves as open, public arenas for permanent discussion, collaboration, and cross-fertilization, not as organizations. According to this interpretation, a forum is "a platform for local civil society" (Fruci 2003: 174). Forums are structured on the basis of informal "work agreements," often foreseeing quite autonomous working groups focusing on specific issues (Fruci 2003; Del Giorgio 2004).

The principles of participation and dialogue, infrequent recourse to voting, time-limited delegation on specific issues, control of delegates, and the consensus method of decision making represent the common organizing elements of local social forums, often marked by the absence of leadership, and the emphasis on horizontal, non-hierarchical relations (Fruci 2003). Local social forums define themselves as networks (on networks see Powell 1990). They present themselves as spaces characterized by a high degree of internal pluralism where individual and collective actors who are very diverse in terms of socio-demographic characteristics and ideological orientation meet each other. A spokesperson for the Abruzzo social forum claimed, "the local forum is made up of different souls: it is the union of diversities without ideological affinity and with theoretical references varying from Naomi Klein, to Alex Zanotelli [an Italian priest espousing liberation theology], to Marx” (interview 2: 6). The code of conduct of the Florence social forum defines its role as "a network structure composed by individual and collective actors 
that share the principles and the analyses contained in the charter. It is an instrument to act at various levels. It is first of all a table for confrontation, not a monolithic political actor. Its subjectivity is expressed in movement forms and it refuses dogmatic positions” (webdocument 7). Similarly, the Catania Social Forum states that the movement is composed of "a kaleidoscope of colours and experiences” (Piazza and Barbagallo 2003: 6). Local political and social structures were reflected in some differences in the structure of the forums. Research on Tuscany indicated that local social forums were more heterogeneous where they opposed local right-wing governments and where there was a tradition of collaboration between different parties and movements (Del Giorgio 2004). Similarly, the building up of a European network of local social forums shows an increased reflection upon the specific conception of democracy behind it, a conception that emphasizes "horizontality" as bottom-up, non-hierarchical networking of individuals and groups with different backgrounds. According to one of the promoters of the European network of local forums, "the idea to build a network among local forums was an answer to the necessity to overcome the schizophrenia of the social forum process where some ideas of horizontality ${ }^{7}$ included in the charter of principles of the WSF that work well when we meet in the European forums and in the European networks, in the everyday praxis of the single countries do not work at all” (interview 1: 2). This main focus was stressed at the first meeting of a European coordination network of local forums which took place during the London ESF in 2004, where, following the strategy "one foot in, one foot out" (Juris 2005) ${ }^{8}$, people from different local forums from all over Europe (Austria, Belgium, France, Germany, Greece, Italy, Hungary, Spain, Sweden, Turkey, UK) organized the seminar "Build locally, link globally: the role and the future of local social forums in Europe", the workshop "the Local Social Forum network in Europe" and an open space. The statement made at the end of the public meeting was reiterated at the supranational level -a conception of the social forum as an experimental arena for exchanges of ideas that had developed at the local level. As the document claimed, "We are a group of participants to local social forums all over Europe, who are networking between local social forums in Europe. The purpose of the network is to get to know each other, learn from each other, build up memories, exchange experiences on operating practices and processes, and on activities taking place in local social forums” (web document 2). This concern with democracy was also reflected in the call to democratize the London ESF process that was promoted, among others, by the people involved in the network of local social forums. The call asked for a more inclusive process and criticized the organizational phase of the third ESF claiming that basic principles of the WSF Charter had been treated with contempt, with organizers employing an opaque and confusing 'faux-consensus', outsourcing ESF functions to private companies, and making the organizing process inaccessible (web document 3). ${ }^{9}$ The European coordination

\footnotetext{
${ }^{7}$ Horizontality has to be understood as "an attempt to allow everyone to become active and direct participants in the decisions and actions that affect them. It implies equality of power in the sense that there is no dictation of directives or obligations to the individual, but rather mutual agreements and commitments" (web document 1 ).

${ }^{8}$ Which means positioning at the margins of the official forum creating autonomous selfmanaged spaces but also being present in the official space of the forum.

${ }^{9}$ During the London ESF, the European network of local forums supported its activity through a mailing-list (http://lists.riseup.net/www/info/eulsf) and a website (http://workspace.fse-esf.org); it also decided to hold regular workshops during the meetings of the European preparatory
} 


\section{JOURNAL OF WORLD-SYSTEMS RESEARCH}

network of local forums organized another seminar during the fourth ESF (webdocument 4) under the title "The Role and future of local social forums." People joining the network produced a common statement that, for the first time, was read during the Assembly of Social Movements (one of the most important events of the ESF, characterized by high visibility and large participation) advocating a bottom-up approach. The statement stressed the role of local forums in the organizational process of the ESF and invited all men and women to contribute more to the social forum process at local levels. Local forums were presented as being able to bridge the local and global levels, providing opportunities for participation and building alternatives (webdocument 4).

Our research on social movement organizations that took part in local social forums indicates that most of the organizational innovations characterizing social forums resonate in the organizations that participated in these arenas and in similar coordination activities. In some cases participation in the social forum process helped to develop innovative organizational ideas that were already present at the foundation of the groups. These new associations, emerging from the GJM, have an organizational structure which is extremely horizontal, networked, and privileges decentralized initiatives around common symbols. This is the case, for example, of the Euro Mayday campaign, a network struggling for recognition of the rights of precarious workers (interview 3), and the Rete Lilliput, an Italian network active on campaigns concerning fair trade, non-violence and ecology (interview 4). Its very name recalls the power of the many little Lilliputians facing the giant Goliath of neoliberalism.

The case of rete Lilliput also reflects efforts to improve its internal democracy through structures able "to facilitate" interaction creating an organism called a 'subnodo' [sub-knot], "with the function of joining and not coordinating but facilitating the local junctures, issueworking groups and so on" (ibid.: 2). Lilliput also brought to the Italian movement new decisionmaking methodologies such as consensus, initially received with skepticism but then adopted by movement organizations at various levels. In the words of an activist:

Lilliput was already using completely different methods, some more effective, some less so, but with great emphasis on the consensus method ... a horizontal approach and the attempt to avoid 'assemblearism' by adopting some precise rules with regards to debates and the decision-making process. These things have also created dissent because initially they were not accepted in the movement whilst later on they were accepted even in other coordinations such as the 'Stop the war' committee" (3).

Although slowing down decision-making (and being criticized for this by the representatives of more decisive organizations, interview 5: 5-6), the consensus method respects different positions often producing more effective decisions as they are more widely shared (interview 4: 5-6). Consensus tries to reach consensual agreement through discussion and good communication. The emphasis is not on unanimity but on the importance of the process of decision making, and of the participation of all members in it. All arguments have to be heard and discussed. In the case of disagreements that involve fundamental beliefs and values, the decision

assembly (in charge of the ESF organization) and to organize a space for local social forums within the 2005 WSF event in Porto Alegre. 
making process can be blocked by a veto. Voting is not excluded, but there has to be consensus that a vote should be taken, and a consensus on the voting method (qualified majority, simple majority, etc.). Social forums also had a transformative effect on older organizations. Local social forums in fact included organizations with longer histories, like those involved in labor conflicts or NGOs active on issues such as solidarity with the South, environmental protection and migrant rights. The first European Social Forum in Florence (2002) had seen a significant presence of several unions - from traditional ones to newly-emerged critical ones, from unions developed in neo-corporatist states to those present in more pluralist ones, from national unions to European confederations, from trade unions to peasants' unions. Unions were also present as members of several coordination committees and network organizations, such as ATTAC and in local social forums.

After the end of the "Fordist-Keynesian" mid-century compromise (Crouch 1999), in Europe large workers' organizations had supported neoliberal policies, (privatization, deregulation and flexibilization of the labor market) implemented even by progressive governments, as inevitable. However by second half of the nineties an opposition to these policies had emerged, both inside and outside the more institutionalized trade unions (see O'Connor 2000; Schoch 2000). Protests against the privatization of public services (in particular transport, schools and health) arose in most European countries (Moody 1997). In countries with pluralist industrialrelations patterns (marked by the presence of multiple representative organizations in competition with each other), new trade unions were heavily critical of privatization, outsourcing and public management doctrine (particularly the introduction of balanced-budget principles). Accused of defending old privileges, public-sector unions often sought public support by claiming to defend public against private values, and services against goods.

Inspired by a new protest cycle, unions amplified their frames beyond the defense of specific workers' rights to issues of citizenship and democracy but also experimented with a new, participatory organizational model. In Italy (but also in France and Spain) the turn of the millennium was characterized by general strikes against pension reform, privatization of public services, and cuts in public health and education. Various networks of movements joined the trade unions, bridging labor issues with those of global justice, defense of the environment, peace and gender equality. The new radical unions criticized the neoliberal turn of other trade unions, but also adopted new models of internal democracy (based on the rotation of leaders and on decisions taken either unanimously or by qualified majority) and joined in with the anti-neoliberal movement (Béroud et al. 1998). In recent years, and in part stimulated by rank-and-file discontent, criticisms of neoliberal economic policies have also been voiced within the traditional trade-union confederations. These unions started to stigmatize social dumping brought on by unrestrained competition among nations based on reducing wages and making labor more flexible, that is, making employment precarious. In fact, the waves of protest against neoliberal globalization seem to have produced a process of "social re-appropriation" (Mc Adam, Tarrow and Tilly 2001) by rank-and-file members of bureaucratized organizations (see della Porta, Andretta, Mosca and Reiter 2006, chap. 2), and innovations by a leadership facing a crisis in membership and influence.

Common to these trends is a critique of the bureaucratization of traditional trade unions and a move towards a more participatory model, and a tendency to "externalize" conflicts emerging in the workplace, where trade unions tend to be weak (Denis 2005: 287). Radical, grassroots trade unions are critical of delegation, in the name of direct worker participation, a 


\section{JOURNAL OF WORLD-SYSTEMS RESEARCH}

forgotten form of democracy in the workplace. One interviewee from a radical union underlined this with an example: "all our proposals have been checked beforehand by the workers. This is the meaning of democracy in the workplace: when you introduce a platform, before discussing it with companies, you present it to the workers and you vote on it in a referendum ... this must concern everything: the national contract, local agreements, etc. They must be voted on in a referendum and it must be a binding referendum" (interview 6: 9). Even if common participation in social forums did not bring radical and traditional trade unions closer together, or unite the traditional trade unions (interviews 7, 8 and 9), the encounter with organizational models external to labor brought about a (renewed) emphasis on participation, that had once characterized labor's original discourse (Reiter 2006).

It has been noted recently that "a decentralized and more democratic organizational structure has replaced a hierarchical and centralized structure” (Passy 2001: 11) not only in labor organizations but also in old solidarity associations whose roots were in the late $19^{\text {th }}$ century. Especially after their encounter with other types of groups and organizational models, organizations with a long history, although not modifying radically their own structures, have introduced several innovations in order to favor and advocate greater participation of their members. More recently formed organizations have adopted decisional methods and structures that radically break with a representative conception of democracy.

Some of the older organizations, where more hierarchical organizational models still prevailed (interview 12: 8), reacted to mobilizations linked to the social forum process by bringing more attention to their member base. Manitese (Italian word for "outstretched hands") a non-governmental development organization founded in 1964 which operates at the national and international level to further justice, solidarity and respect among peoples (webdocument 8) - has started to reflect on its own decisional methods, producing several changes, promoting "a shift from a hierarchical management determined by the past to a shared formula with several units" (interview 13: 6-7), as well as some experimentation with consensus-based decisions.

Recent organizations engaged in international cooperation have also been affected. Emergency is such a case. It is an independent, neutral and non-political Italian organization founded in order to provide free, high quality medical and surgical treatment to the civilian victims of war, landmines and poverty (webdocument 9). The movement has brought about a crisis of growth in the organization, provoked not only by the exponential increase in the demand for information but also for participation (interview 14: 1-2). This challenge led to a more participative conception of the organization. As a volunteer put it, "it is as if a little baby suddenly became an adult and took steps forward too quickly, so we have almost collapsed ... we have had moments of great tension because of the pressures we have felt on us ... and this has been the impulse for all changes... one year ago we created the territorial groups... the associates' assembly has also increased in terms of number of participants” (13).

The encounter with the social forum process and in particular with the Zapatistas experiences brought changes even in the decentralized and participatory organizational model promoted by the youth squatters in social centres ${ }^{10}$, that represent an important part of the Italian movement (interviews 10 and 11). In these groups, cross-fertilization with other experiences (in

${ }^{10}$ Social centres are communities managed by young politically engaged people (mainly students and unemployed) who squat unused buildings where they organize social, political and cultural activities. 
particular with the Zapatistas) was reflected in a growing attention to conceptions of deliberative democracy, especially those that linked "horizontal" forms of assembly and participation to the transformative power of consensual methods.

Hence, the organizational structures of the movement appear flexible and mutable, with a "variable geometry" configuration (Castells 1996) made of decompositions and continuous recompositions in which the end of an experience often constitutes also the seed that leads to the generation of new groups. In the "spirit of Porto Alegre", the method of consensus offered an instrument to organize a diverse and broad base; as an interviewee put it, "even if the social forums' structure in Milan did not persist, a thousand things arose in other places and, in any case, we have known each other at least on a personal level and we carry on meetings so it has certainly started a participative process” (interview 16: 5).

\section{TRANSFORMATIONS IN THE FRAMING: THE GLOBAL IN THE LOCAL}

"The Novara social forum, which is based in our city, aims to coordinate with national and international social forums, oppose neoliberal globalization and build together a new narration of the world for the globalization of rights, solidarity, and peace ... We commit ourselves to "territorialize" the movement, addressing local issues on the themes of labor, environment, health, consumption, communication, education and rights" (webdocument 11).

The aim of the movement is "to spread direct participation and citizenship to defend common goods from private economic aggression and to re-establish priority of politics on economics" (interview 20).

The first quotation, above is taken from the Novara social forum constitution, and clearly indicates neo-liberalism to be the main enemy of the GJM. It also stresses the important function of translation from the transnational to the local level. In the second quotation of an activist from the Venice social forum describes what, according to its organization, is the main scope of the movement; the definition and defense of the "public good" against market liberalization is also mentioned by a spokesperson of the Abruzzo social forum (interviews 2). The innovations in the organizational formulas described previously, with the increasing influence of a networked structure, interacted with the development of a specific conception of a multilevel and multi-issue identity, as expressed in the mentioned slogan "Build locally, link globally". In the construction of collective identities, the local social forums stress two linkages. First of all, they aim at bridging the global and the local, by "territorializing" the movement. On the one hand, local social forums translate and re-frame global issues in local environments; on the other, they link local struggles with global concerns on democracy, participation and social justice. They push for a combination of local roots with global visions. Stressing this aim, the charter of the Florence local social forum states, "We are individual citizens, unions and associations, movements and self-organized groups, Florentine political and social actors that assemble in the social forum of Florence. We feel part of an international movement that aims at challenging the oligarchies and their anti-democratic procedures, represented by the big global economic and military organizations” (web document 10). 


\section{JOURNAL OF WORLD-SYSTEMS RESEARCH}

Besides, most of the local social forums present a multi-level model of mobilization being active in specific territories but also mobilizing in national and transnational campaigns and coalitions active on multiple issues. In this sense, they inverted the evolution towards specialization on single-issues experienced by social movements of the eighties and the nineties (i.e., see della Porta 1996 for the Italian movement and Ranci 2001 for solidarity movements). Social forums acted in fact as bridges between different movements. One of their main features is indeed their composite nature based on the convergence of various social and political actors who, in the past, have often competed with each other or, at least, focused on different issues (della Porta 2006). Local social forums therefore understand themselves as political laboratories, arenas of interaction and planning of further activities and actions, spaces where a common identity stems from the encounter of different individual and collective actors. According to one of the promoters of the European network, the coordination is not supposed to launch common mobilizations and campaigns, as this task is developed by the European Assembly of Social Movements, but "to encourage the birth of new local forums, spread our experience recognizing the diversity of the forums from one country to another ... grow together, stimulate those that had not yet tried to create a forum and exchanging experiences that we are practicing ..." (interview no 1: 7).

Social forums were able to spread multi-issue frames across the various groups that took part in them. An activist of the Florentine social forum during a focus group stressed the innovation brought in by the forum considering it "a great novelty and a huge asset as it brings together men and women, from twenty to sixty, who discuss with each other, opposing the logic of the old leftist parties of separating women, young people and so on" (quoted in della Porta 2005a: 186). The main added value of the forum is "to put in contacts situations that in the past years had not met enough, or met only during emergencies, for short periods... this is instead the first experience I live that is so alive in terms of contacts and networking, where being in contact and being in a net is the most important element ... this is the most positive part... the value of the social forums..." (ibid.: 89). In the words of the same activist, "the forum has something evangelic, new, that we were waiting for... in the way of discussing, exchanging ideas, getting in contact with each other in a different ways, of avoiding conflicts and so linking together very different components, that now look at each other in a different way" (ibid.: 144).

Meeting in the forum contributed to a sort of opening up of organizational and individual identities, first of all by the bridging of different frames. Although with different emphases, the radical trade unions present themselves as not only social, but also political actors who frame their specific interventions on labor issues in a more complex vision of society. As an activist told us, "it was our understanding that it was necessary to avoid a model in which unionist claims only concern for your salary and then leave to political representation the issues of what kind of school you want, what its perspectives should be, what the social function of your work should be. This classic division of labor between what pertains to the trade unions and what pertains to the role of political parties in parliament was challenged” (interview 11: 3).

During more recent protests, identification between the working class and citizens more generally has been strengthened. According to one representative of the Sindacato dei Lavoratori Autorganizzati Intercategoriale Cobas (SLAI COBAS, http://www.slaicobas.it), in the transport sector of Milan a "wild” strike held on December 2003 produced solidarity because the drivers were also striking in the name of workers who did not have the possibility of striking, "The worker does not have the minimal possibility of protecting himself, of protecting his salary, the 
rights he has obtained etc. so we, the people who were breaking that system, have been seen as instituting revenge, as if 'finally someone tried it' and the citizens have been even stronger than the media: that was an exceptional thing” (interview 6: 5).

In the unions' environment, apart from recalling class identity, there has been attention also to a redefinition of the concept and the function of labor. This innovation is particularly visible in the organizations that emerged from the movement, combining labor issues with societal ones. The Chainworkers ${ }^{11}$ discourse emerged with the diffusion of temporary work in commercial chains like Blockbuster and McDonald's but then "we started to talk about social temporariness" to the "whole working class ... not just workers in the commercial chains. This was something much larger. The message was extended to all working categories because we realized that this process of increasing job insecurity was involving not only the commercial chains but all the companies too, in the sense that the new workers were not hired but signed temporary contracts" (interview 3: 1). The action on temporary work, organized around the ironic symbol of San Precario (saint of precarious workers), was extended from labor issues to everyday life, "Saint Precario has five axes of security which are: income, house, love and friendship, access and services. So within these five themes it is always possible to find a kind of affinity with other people" (ibid.: 11). The challenge to the conception of labor is also perceived in more traditional unions. For example, as the Federazione Impiegati Operai Metallurgici (FIOM, http://www.fiom.cgil.it) representative emphasizes the growing presence of temporary workers challenge the traditional approach to labor (interview 17: 3).

New and "political" identities also developed in the galaxy of organizations engaged on the issue of international solidarity. First it should be emphasized that these organizations have developed a genuine political orientation: "Behind their demands - for the respect of human rights, against racism, for helping the third world, in defence of immigrant workers and political refugees - there is a quest for individual emancipation and a deep democratization both of Western and non-Western society” (Passy 2001: 10).

In more traditional associations participation in the social forum process pushed them towards innovations in their identity. For the Associazione Ricreativa Culturale Italiana (ARCI) ${ }^{12}$, which was founded in 1957 as a collateral association to the Italian Communist Party but became more autonomous over time, the redefinition of its identity has entailed a strong commitment to the issue of peace (interview 19: 1). Manitese also has a long history and, over time, the generational and territorial heterogeneity of the association substantially increased bringing about a re-elaboration of its organizational identity with the development of local perspectives "very committed also from a political point of view and working in contact with Zapatista movements, which means that they reflect more deeply on globalization issues” (interview 13: 5).

With certain differences, the outcome of participation in local social forums and similar activities accompanying the emergence of the movement is the singling out of a global stake in opposing neo-liberalism. Recognition of similarities across countries through involvement in

${ }^{11}$ Chain Workers is a group based in Milan that aims at mobilizing precarious workers of malls and supermarkets through public demonstrations and picketing (for more information, see: http://www.chainworkers.org).

${ }_{12}$ An association for social promotion with 1.2 million members, 6,000 clubs and permanent chapters all over the national territory, 126 territorial and regional boards; dealing with culture, public delegations and free time. 


\section{JOURNAL OF WORLD-SYSTEMS RESEARCH}

international networks enables the construction of a supranational identity, as in the case of solidarity movements (Smith 2001). From this perspective the representative of the radical union Sindacato dei Lavoratori Intercategoriale Cobas (SIN COBAS, http://www.sincobas.org) reminds us:

The desire for projection at an international level is reflected in our symbol which contains the acronym 'Solidarity. Unity. Democracy'. This is not by chance: in the same years in France the radical union Solidarité, Unité, Democratié ("Solidarity, Unity, Democracy"-SUD) emerged, and given that we had this contact ... the common idea was that we had to become a European trade union ... In some way, this implied evoking a European trade union rather than constructing it, evoking it by including such words in the symbol” (interview 10: 4).

Generally speaking, the process of neoliberal globalization has become a reference point for a definition of the group's identity. As our interviewee adds, "it is obvious that whenever you reflect on issues such as cooperation, North-South inequality, the exploitation of child labor ... globalization is the context ... at the basis of everything there is a critique of the economic system as entailing growth without limits, and it's not just a critique of inequalities ... but a critique of growth as such and of development” (ibid.: 4-6). Also in many other groups, the collective identity has been modeled around the criticism of neoliberal globalization and war. The very issue of opposition to war provides links to more moderate organizations (interview 12: 2-3). Such developments are signaled by the representative of a more traditional organization such as the ARCI (which was one of the main organizers of the first European Social Forum held in Florence in 2002) and by the Christian labor association Associazioni Cristiane Lavoratori Italiani (ACLI, http://www.acli.it), "a group of young ACLI members accelerated the number of practical actions on the issue of peace in the international area... from there a sensibility for more practical actions matured, and there was a change in the international arena which led to this new structure, to a new way of looking at things" (interview 12: 1). Symbols and myths in fact help distant actors to identify with one another - as in the case of the "Zapatistas' experience" in which radical unions as well as international solidarity organizations have been involved (interviews 10 and 13).

\section{LOCAL SOCIAL FORUMS AS BRIDGES: CONCLUSION}

By focusing on Italian local social forums as well as some of the organizations engaged in them, we underlined how various organizational networks active on different issues have interconnected and mobilized together, generalizing their claims, extending beyond national borders and experimenting with alternative organizational formulas. This process involved both organizations coming from previous cycles of protest and organizations born after the "battle of Seattle” in 1999.

As we have seen, novel aspects of structure and process developed in the organizational formulas. Formed by rooted cosmopolitans, local social forums contributed to bridging different territorial levels. Local social forums cultivated a networked structure, defining themselves as 
arenas for mutual learning between individuals and groups with different previous political and social experiences. Participation in these networks had indeed a transforming impact on those who took part in them. More traditional organizations tend to maintain hierarchical structures but with a more participative conception of the organization; organizations founded during the waves of anti-neoliberal protests are characterized instead by a highly flexible and networked structure and decisional methods oriented towards participation and consensus formation.

As far as identity is concerned, participation in the social forum process promoted a reshaping of organizational identities constructed in opposition to neoliberal globalization. As local forums tend to frame their activities in terms of global struggles and mobilize also at the transnational level, supranational identities tend to emerge among actors involved in this type of coordination. Participation in local forums is reflected in frame-bridging on several issues. During forum planning some of the frames and organizational strategies proposed by new groups found resonance in traditional organizations which were influenced by their encounter with emerging organizations.

The local forum formula contributed to spreading a logic of networking and multi-issue involvement (political and social at the same time) that became central to many movement organizations. The precarious nature of some ad-hoc experiences-which emerged to coordinate specific campaigns and then dissolved themselves - was not perceived as a weakness but rather as an opportunity for future initiatives. As a representative of the ARCI puts it, "this very elastic and open model is used when needed, and we know that this is the system and the model: a platform is proposed and all the people who agree join each other. Then, as it arose, this thing may disappear, but what you still have is the method" (interview 19: 19).

The rhizomatic evolution (emergence, disappearance, and re-emergence) of local social forums in recent years testifies to the difficulties of building permanent arenas of encounters. In some cases, such as in the big cities (Milan but also Rome), the very size of the first meetings (involving hundreds of groups and thousands of activists) made the process unmanageable. In others cases the decline followed some general ebbs in the mobilization, or the opening up of other networking spaces (e.g., for the organization of peace protests). Sustaining common spaces of coordination and mobilization is indeed a difficult task. As one of the promoters of the European local forums network puts it, "Working with a forum logic is definitely hard... it is the most difficult thing in the world as you have to abandon your organizational belonging, you have to accept differences, you have to accept a method based on listening and not on imposition and to define common objectives in a constant and common work" (interview 1: 5). Local social forums tended in fact to remain active especially in those areas where widespread local struggles against large infrastructure projects sustain mobilization processes. Examples include local social forums that are still active in large protest campaigns against the high-speed train in Val di Susa and the Bridge on the Messina Strait (della Porta and Piazza 2008), but also those opposing a flood barrier system against the high tide and the sinking of Venice, the construction of a highway tunnel in the mountain chain of the Gran Sasso in Abruzzo, and the F-35 Joint Strike Fighter program supposed to locate a part of the production near Novara (interview 2, 20 and 21). This means that the reference to an 'abstract' transnational forum process is a necessary but not sufficient condition to keep local social forums alive.

However, even when these pluralist arenas collapsed, innovations concerning organizational formulas, as well as multi-issue and transnational frames remain a part of the repertoire of collective action exerting a durable impact on local settings. Thanks to the previous 


\section{JOURNAL OF WORLD-SYSTEMS RESEARCH}

experience with local forums, new coalitions, networks, and roundtables with "variable geometry" configuration can be easily and rapidly formed depending on the issues and the targets of different campaigns. The social forum process can then be considered relevant not only in and of itself but also for its capacity to produce long-lasting transformations in, and cross-fertilization of, the organizations that have been involved in such a process.

As argued elsewhere (della Porta and Mosca 2007), pluralist arenas like local social forums created the conditions for different actors to meet and discuss. The plurality of associative and thematic commitments on the part of the activists, and the affiliation of the organizations themselves in networks facilitated a process of 'contamination in action' that helps logistical coordination, enables the emergence of tolerance for differences and mutual trust and allows frame-bridging and the transnationalization of identities. Trust among activists developed in transnational campaigns was transferred to the local level, and vice-versa. Local social forums as arenas for exchange of ideas played a cognitive role in the import, but also the translation of new ideas. They thus helped dense network structures and tolerant identities to develop.

In sum, ideas travelled cross-level, from the local to the global and vice-versa. Research on diffusion among social movements has looked at how ideas concerning organizational structure, strategies of action, or definitions of the world 'travel' from movement to movement, sector to sector, city to city, center to periphery and, on occasion, from periphery to center (McAdam and Rucht 1993; Soule 2004). While the role of structural (or geographical) proximity and direct linkages in facilitating diffusion has been stressed, the symbolic construction of similarities which travel through indirect channels also plays an important role. Besides direct interactions or structural similarities, the 'cultural understanding that social entities belong to a common social category [also] constructs a tie between them' (Strand and Meyer 1993: 490). Regardless of actual similarities, in fact, the subjective perception of common circumstances leads to an idea being considered relevant and adopted. While some visions of diffusion stress its unreflective, unconscious nature, research on social movements has instead emphasized the active role of social movement activists as adopters and adapters of ideas coming from other movements or other places. In this sense, particularly relevant is the presence of spaces and actors for communication beyond borders. The rich and varied repertoire of action of new global movements is indeed the product of enhanced occasions for transnational encounters (della Porta and Diani 2006, chap. 7).

This article highlights in particular that the work of translating the global to local settings requires the presence of bridges or brokers facilitating such a process. As Diani (2003: 107) noted, 'brokers' most crucial property lies in their capacity to connect actors who are not communicating because of some specific political or social barrier ... brokerage is crucial for the survival of chains of interaction, and therefore for the connectedness of a network as a whole." In the specific cases under study, leaders or innovators in the process were people who had experiences in larger WSF/ESF contexts and/or with cross-movement coalition building. The role of these "rooted cosmopolitans" as translators, who help make the connections across diverse constituencies, seems to be an important element of the processes described in this article. However, "rooted cosmopolitans" do not just translate but also interpret and re-contextualize foreign ideas and practices in domestic arenas (Roggeband 2007). Besides, the process of translation requires some specific conditions in the potential adopters. In the case of more traditional social movement organizations which tend to be more hierarchical (see also Wood 2005: 105) and not specifically mobilized around global justice (i.e. trade unions), some leaders 
who attended the ESFs and the WSFs found it difficult to translate the "social forum spirit" into their organizational settings at the local level (interviews 7, 8 and 17). The process of translation seems indeed to work more effectively at the horizontal level (between different organizations) than at the vertical one (from the top to the bottom), but more specific research is necessary to investigate in detail the potential and limits of cross-level diffusion of ideas.

\section{REFERENCES}

Andretta, Massimiliano, Donatella della Porta, Lorenzo Mosca, and Herbert Reiter. 2002. Global, noglobal, new global. Le proteste contro il G8 a Genova. Roma-Bari: Laterza.

Béroud, Sophie, René Mouriaux and Michel Vakaloulis. 1998. Le movement social en France: essai de sociologie politique. Paris: La Dispute.

Castells, Manuel. 1996. The Rise of the Network Society. Oxford: Blackwell.

Crouch, Colin. 1999. Social Change in Western Europe. Oxford: Oxford University Press.

Del Giorgio, Elena. 2004. "I Social Forum in Toscana. Funzionamento e rapporto con il contesto locale di arene deliberative in costruzione." Pp. 155-176 in La Toscana e la globalizzazione dal basso, edited by E. Diodato, Florence: Chiari.

De Sousa Santos, Boaventura. 2008. "The World Social Forum and the Global Left”, Politics \& Society, 36:247-270.

della Porta, Donatella. 1996. Movimenti collettivi e sistema politico in Italia, 1960-1995. RomaBari: Laterza.

2005a. "Multiple belongings, tolerant identities, and the construction of 'another politics': between the European social forum and the local social fora." Pp. 175-202 in Transnational Protest and Global Activism, edited by D. della Porta and S. Tarrow, Lanham (UK): Rowman \& Littlefield.

. 2005b. "Making the Polis: Social Forums and Democracy in the Global Justice Movement”. Mobilization 10:73-94.

. 2005c. "Deliberation in Movement: Why and How to Study Deliberative Democracy and Social Movements.” Acta Politica, 40:336-350.

. 2006. "From corporatist unions to protest unions? On the (difficult) relations between organized labor and new social movements." Pp. 71-97 in The Diversity of Democracy. Corporatism, Social Order and Political Conflict, edited by C. Crouch and W. Streeck, Chelteham: Edward Elgar.

(ed.). 2007. The Global Justice Movement: Cross-national and Transnational Perspectives. Boulder: Paradigm Publishers.

della Porta, Donatella, Massimiliano Andretta, Lorenzo Mosca and Herbert Reiter, 2006, Globalization from below. Transnational activists and protest networks. Minneapolis: The University of Minnesota Press.

della Porta, Donatella, and Lorenzo Mosca. 2007. "In movimento. Organizational dynamics in the emergence of the global justice movement.” Global Networks. 7:1-27.

della Porta, Donatella and Gianni Piazza. 2008. Voices of the Valley. Voices of the Straits. How Protest Creates Community, Oxford-New York: Berghahn Books. 
Della Porta, Donatella and Sidney Tarrow. 2005. "Transnational Processes and Social Activisms: An Introduction.”, Pp. 1-20 in Transnational Protest and Global Activism, edited by D. della Porta and S. Tarrow, Lahham: Rowman and Littlefield.

Denis, Jean-Michel. 2005. “La constistution d'un front antilibéral : L’union syndicale groupe des dix-Solidaires et ATTAC.” Pp. 265-290 in L'altermondialisme en France. La longue histoire d'une nouvelle cause, edited by E. Agrikoliansky, O. Fillieule and N. Mayer, Paris: Flammarion.

Diani, Mario. 2003. “'Leaders' or 'brokers'? Positions and influence in social movement networks.” Pp. 105-122 in Social movements and networks, edited by M. Diani and D. McAdam, Oxford [etc.]: Oxford university press.

Drainville, André C. 2004. Contesting globalization, London: Routledge.

Fruci, Gian Luca. 2003. "La nuova agorà. I social forum tra spazio pubblico e dinamiche organizzative.” Pp. 169-200 in La democrazia dei movimenti, edited by P. Ceri, Soveria Mannelli: Rubettino.

McAdam, Doug and Rucht, Dieter. 1993. "The Cross-national Diffusion of Movement Ideas.” The Annals of the AAPSS, 528:56-74.

McAdam, Doug, Tarrow, Sidney and Charles Tilly. 2001. Dynamics of Contention. Cambridge: Cambridge University Press.

Moody, Kim. 1997. Workers in a Lean World. London, New York: Verso.

O’Connor, Jim. 2000. "Die Konferenz von Seattle und die Anti-WTO-Bewegung.” PROKLA. Zeitschrift fuer kritische Sozialwissenschaft 118:157-170.

Passy, Florence. 2001. "Political Altruism and the Solidarity Movement: An Introduction.” Pp. 325 in Political Altruism? Solidarity Movements in International Perspective. Edited by M. Giugni and F. Passy, Lanham, Boulder, New York, Oxford: Rowman \& Littlefield.

Piazza, Gianni, and Marco Barbagallo. 2003. “Tra globale e locale. L’articolazione territoriale del movimento per una globalizzazione dal basso: i social forum in Sicilia”. Paper presented at the annual congress of the Italian Political Science Association, Trento, September.

Pleyers, Geoffrey. 2007. Forums Sociaux Mondiaux et défis de l'altermondialisme, Bruxelles: Academia-Bruylant.

Powell, Walter W. 1990. "Neither Market Nor Hierarchy: Network Forms of Organization.” Research in Organizational Behavior 12:295-336.

Ranci, Costanzo. 2001. "Altruism in Voluntary Organizations. Mobilization and Transformation of Voluntary Action in Italy.” Pp. 67-86 in Political Altruism? Solidarity Movements in International Perspective, edited by M. Giugni and F. Passy, Lanham, Boulder, New York, Oxford: Rowman \& Littlefield.

Reiter, Herbert. 2006. "Organizational ideology and visions of democracy of Italian Global Justice Movement Organizations.” Pp. 224-264 in Organizational ideology and visions of democracy in the Global Justice Movement, edited by d. della Porta and H. Reiter. WP3 report of the Demos project (http://demos.eui.eu).

Roggeband, Conny. 2007. "Translators and transformers: international inspiration and exchange in social movements,” Social Movement Studies, 6: 245-259.

Schoch, James. 2000. "Contesting Globalization: Organized Labor, NAFTA, and the 1997 and 1998 Fast-Track Fights”. Politics \& Society 28:119-150. 
Soule, Sarah. 2004. "Diffusion Process Within and Across Movements.” Pp. 294-310 in The Blackwell Companion to Social Movements, edited by D.A. Snow, S.H. Soule and H. Kriesi, Oxford: Blackwell.

Strand, David and Meyer, John W. 1993. "Institutional Conditions for Diffusion.” Theory and Society, 22:487-511.

Tarrow, Sidney. 2005. The New Transnational Activism. Cambridge: Cambridge University Press.

Wood, Lesley. 2005. Bridging the Chasms: The Case of People’s Global Action. Pp. 95-117 in Coalitions across Borders. Transnational Protest and the Neoliberal Order, edited by J. Bandy and J. Smith, Lanham (UK): Rowman \& Littlefield.

\section{INTERVIEWS}

1. Promoter of the European network of local social forums

2. Spokepersons of the Abruzzo social forum

3. Activist of the group Chainworkers and EuroMayDay campaign

4. Activist of the Lilliput Network

5. President of the association Associazione per i Consumi Etici e Alternativi (ACEA)

6. Delegate of the radical union Sindacato dei Lavoratori Autorganizzato Intercategoriale (SLAI COBAS) in the ATM (Milanese public transport)

7. Confederazione Italiana Sindacati dei Lavoratori (CISL) union member responsible for relations with the movements in Milan

8. Confederazione Generale Italiana del Lavoro (CGIL) union member formerly responsible of the relations with the movements in Milan

9. Delegate of the union Federazione Italiana Lavoratori Trasporti - Confederazione GeneraleItaliana del Lavoro (FILT-CGIL) in the ATM (Milanese public transport)

10. National secretary of the radical union (Sindacato Intercategoriale dei Comitati di Base) SIN COBAS

11. Delegate of the radical union Comitati di Base della Scuola (COBAS-school) in Milan

12. Responsible of the international department of the catholic association Associazioni Cristiane Lavoratori Italiani (ACLI) in Milan

13. Voluntary of the association Manitese

14. Responsible of the volunteers in the association Emergency

15. President of the fair trade cooperative Chico Mendes

16. Activist of the working group on Critical Consumerism of the Milan social forum

17. Responsible of the international office of the metalworker union Federazione Impiegati Operai Metalmeccanici (FIOM) in Milan

18. Voluntary of the association "Un Ponte per"

19. Organizational responsible of the association Associazione Ricreativa Culturale Italiana (ARCI) in the province of Milan

20. Member of the Venice social forum

21. Member of the Novara social forum 


\section{JOURNAL OF WORLD-SYSTEMS RESEARCH}

\section{WEB DOCUMENTS}

1. Horizontalidad (http://en.wikipedia.org/wiki/Horizontality; accessed 15 October 2007).

2. LSF, December

2004 (https://wiki.sheffieldsocialforum.org.uk/LSFDec2004\#EU_LSF_statement; accessed 22 June 2007).

3. Sign-on statement to democratise the ESF!

(http://www.indymedia.org.uk/en/2004/02/286049.html; accessed 22 June 2007).

4. Statement from participants in local social forums gathered in Athens ESF May 2006 (http://www.openspaceforum.net/pipermail/worldsocialforum-

discuss_openspaceforum.net/2006-May/000181.html; accessed 22 June 2007).

5. Carta di intenti del Torino social forum [Charter of intents of the Turin social forum] (http://www.lacaverna.it/comunicati/cartadiintenti1.htm; 15 October 2007).

6. Proposta di struttura organizzativa del Torino social forum [Proposal for an organizational structure of the Turin social forum] (http://www.lacaverna.it/comunicati/organizzazione.htm; 15 October 2007).

7. Bozza di regolamento per il funzionamento del social forum di Firenze [Draft of regulation for the functioning of the Florence social forum]

(http://firenzesocialforum.net/regolamentofsf.html; accessed 10 September 2005).

8. Manitese. Who we are \& what we do (http://www.manitese.it/index.php?english; accessed 22 June 2007).

9. Emergency. Who we are (http://www.emergency.it/menu.php?A=001\&ln=En; accessed 22 June 2007).

10. Carta del forum sociale di Firenze (http://firenzesocialforum.net/cartafsf.html; accessed 10 September 2005).

11. Patto di lavoro del Novara social forum (http://digilander.libero.it/novarasocialforum/patto.htm, accessed 6 July 2008). 